\title{
Net aerial primary productivity, litter production and decomposition of the reed Phragmites communis in a nature reserve in Hong Kong: management implications
}

\author{
S. Y. Lee \\ Department of Zoology, University of Hong Kong, Hong Kong
}

\begin{abstract}
Mean net aerial primary productivity of Phragmites communis (L.) Trin. amounted to $2198.3 \pm 416.7 \mathrm{~g}$ dry $w t \mathrm{~m}^{-2} \mathrm{yr}^{-1}\left(8.24 \pm 1.56 \times 10^{7} \mathrm{kcal} \mathrm{m}^{-2} \mathrm{yr}^{-1}\right)$ in the Mai Po Marshes, a nature reserve for migrant birds in Hong Kong. Success of $P$. communis is also reflected by the high mean aerial

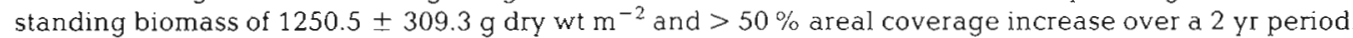
Litter production was estimated as $504.9 \pm 212.7 \mathrm{~g}$ dry wt m $\mathrm{m}^{-2} \mathrm{yr}^{-1}$ Export of litter was only $0.06 \%$ of production; the bulk of litter was thus accumulated and decomposed in situ. Decomposition of litter was influenced by temperature and inundation regimes, the rate at $52.5 \%$ air exposure being significantly higher than at 13.5 and $2.5 \%$ exposure. Cumulated day-degree and cumulated immersion time were better predictors of decomposition rates than time alone. Higher decomposition rates at intermediate exposure were probably related to phylloplane algal growth, which gave the litter very low C:N ratios, attracting grazing gastropods. Success of $P$. communis is probably related to the high accretion rate and to traditional management practices which are complementary to the seasonal growth cycle. Rapid spread of the reed may decrease the open area available to waterfowl and their prey, and may also encourage further accretion. Clipping at peak biomass in autumn coupled with hydroperiod and water level management are possible natural ways of control.
\end{abstract}

\section{INTRODUCTION}

The wide occurrence and dominance of Spartina spp. in temperate coastal wetlands in the western hemisphere has invited much research on production of members of the genus. With increasing recognition of the conservation values of coastal wetlands, a knowledge of the biology of key organisms like Spartina is essential. Dominance of Spartina along the Atlantic coast of North America has often been displaced by invasions of the reed Phragmites australis (Cav.) Trin. ex Steud. (probably synonymous with $P$. communis Trin. [Clayton 1968, Haslam 1972] and considered as such in following discussions) in areas subject to significant anthropogenic disturbances (Phillips 1987). Although seed germination and growth of $P$. communis may be inhibited by elevated salinities (Haslam 1972), high percentage germination is not retarded at $0.5 \%$ (Galinato \& van der Valk 1986, Matoh et al. 1988) and fast coastal colonization occurs in situations where combined effects of original vegetation disturbance, substrate elevation and decreased salinity prevail (Roman et al. 1984, Schleyer \& Roberts 1987).

The cosmopolitan distribution, high resilience and extreme productivity of Phragmites spp. (Haslam 1972, Björndahl 1985, Davis \& Briggs 1986, Maltby 1986) warrant more studies on its role in wetland ecosystems, particularly in the tropics of the eastern hemisphere where conservation efforts have been hampered by an inadequate database even for important species like $P$. communis. As for Spartina spp., comparatively few reports have examined the ecological role of the species in the marsh ecosystem which it often dominates.

In tidal shrimp ponds (locally known as the gei wais') in the Mai Po Marshes, a nature reserve for migrant birds in northwest Hong Kong, Phragmites communis has achieved co-dominance with the native mangrove Kandelia candel (L.) Druce. The spread of the reed not only implies a shift in the dominant source 
of primary production, but also a change in the landscape of the ponds, both aspects being important to the wildlife conservation and fishery objectives of the area.

In this study, the net aboveground primary productivity (NAPP) and litter dynamics of Phragmites communis were assessed at the Mai Po Marshes, Hong Kong, to quantify the importance of this species in the functioning of the ecosystem. Possible management implications of these findings are also discussed.

\section{MATERIALS AND METHODS}

Study area. All sampling and experiments were conducted in a tidal shrimp pond ('gei wai', no. 18, 9.1 ha) in the Mai Po Marshes, northwest Hong Kong (Lee 1989a). The ponds are utilised for extensive shrimp and fish culture, relying on incoming water for both larval stock and food. The pond communicates with outer Deep Bay through a single seaward sluice gate measuring $1.70(\mathrm{H}) \times 1.35 \mathrm{~m}(\mathrm{~W})$. Details of operational methods can be found in Macintosh (1983). Such landscape is a common feature throughout coastal mangroves in southeast Asia. Its Indonesian equivalent, the tambak, has a history of about $400 \mathrm{yr}$ and occupied about $2.25 \times 10^{5}$ ha in 1984 (Cholik \& Poernomo 1987). The gei wais in Hong Kong were excavated from the native mangroves of a mixed Kandelia candel, Avicennia marina and Aegiceras comiculatum formation along the Pearl River Estuary in the 1940's. A total of 250 bird species can be recorded from the marshes throughout the year. Unlike the tambaks, patches of mangroves are still retained in the ponds.

Net aboveground primary productivity (NAPP). NAPP of Phragmites communis stands in gei wai 18 was measured over a 2 yr period using the paired plot method of Wiegert \& Evans (1964). This method works best in highly homogeneous areas, which is usually the case for monospecific $P$. communis stands (Roberts et al. 1985).

Eight paired plots each comprising two $0.25 \mathrm{~m}^{2}$ subplots were randomly selected from monotypic Phragmites communis stands. All aerial growth was clipped to ground level in both plots and the materials from one ( $N$ plot) of them were marked and collected for later analysis. All dead material on the ground in the $\mathrm{N}$ plot was also collected and kept in plastic bags. The other plot of the pair (the R plot) was fenced with nylon mesh to prevent export and import of dead plant material. During the following visit, material remaining in the $\mathrm{R}$ plot was retrieved and a new pair of plots similarly sampled. This procedure was repeated at monthly intervals from December 1985 to November 1987.

In the laboratory, the aerial biomass was separated into components of (1) culms, (2) green leaves, (3) dead leaves and (4) flower plumes. The dry weights of the respective components were recorded from each plot after drying at $80^{\circ} \mathrm{C}$ for $48 \mathrm{~h}$. Dead leaves were distinguished by their grayish-brown colour and brittleness The sum of components (1), (2) and (4) gave the aboveground biomass. Component (3) represented the amount of dead material (D).

Dead materials collected from the plots were washed on a $2 \mathrm{~mm}$ sieve to remove mud and periphytic growth before drying at $80^{\circ} \mathrm{C}$ for $48 \mathrm{~h}$ to give dry weights. A comparison of the dry weights of dead material from the $R$ and $N$ plots allows an estimation of the rate of disappearance of dead material:

$$
r=\frac{2\left(D_{N, i}-D_{R, i+1}\right) /\left(D_{N, i}+D_{R, i+1}\right)}{t_{i+1}-t_{i}}
$$

(Roberts et al. 1985)

where $D_{N_{1}}=$ mean dry weight of material in the $\mathrm{N}$ plot at $t_{i} ; D_{R_{1}+1}=$ mean dry weight of material in the $R$ plot at $t_{1+1} ; t_{i+1}-t_{i}=$ time between harvests; and $r=$ proportion of dead material lost during the interval $t_{i+1}-t_{i}$.

Unlike the original equation of Wiegert \& Evans (1964), which assumes a negative exponential model, this estimation assumes no particular model for the rate of loss and probably gives better estimates of loss in the marsh environment (Linthurst \& Reimold 1978).

Values of NAPP for the plots were calculated by the equation

$$
P_{N}=\sum\left(\delta B+d_{d}+\delta D\right)
$$

where $\delta \mathrm{B}=$ positive changes in standing biomass; $\delta \mathrm{D}$ $=$ positive changes in standing dead material; and $d_{d}=$ loss by decomposition $=r\left(t_{1+1}-t_{1}\right) \times 0.5\left(D_{i}+D_{i+1}\right)$ $r$ being the average rate of decomposition for the site.

The value of $P_{N}$ was also calculated using the average values of $B, D$ and $r$ for pooled data from all sites.

Annual changes in the standing biomass of dead material plus all decomposition losses under the Phragmites communis stands also provided a method to estimate the litter production rate:

$$
\mathrm{L}=\sum\left(\delta \mathrm{D}+\mathrm{d}_{\mathrm{d}}\right)
$$

In order to estimate belowground production, 5 replicate samples of above and belowground growth were obtained at the start of the study (December 1986). The rhizomes and roots were cleaned of superficial mud and dried at $80^{\circ} \mathrm{C}$ for $48 \mathrm{~h}$ to obtain an approximate conversion factor from aboveground to belowground biomass.

The energy contents of the various components were measured by a Parr semi-micro bomb calorimeter, using ca $1 \mathrm{~g}$ of oven-dried, ground and pooled material. Five replicates were measured for each component.

Litter dynamics. Decomposition of litter: Brown, dead leaves of Phragmites communis were collected 
from gei wai 18 in September 1987. The leaves were then air-dried at $23^{\circ} \mathrm{C}$ before weights of individual leaves were recorded to the nearest $\mathrm{mg}$. Five leaves were then sealed in separate compartments of nylon mesh bags $(2 \mathrm{~mm}$ mesh) measuring $25 \times 25 \mathrm{~cm}$. The leaves were laid flat to avoid folding in the compartments.

In order to estimate decomposition rates of the litter at different inundation frequencies, 18 litter bags were set at each of 3 levels in an open mud flat area of the study pond. The levels at the upper (U), middle (M) and the lower (L) stations corresponded, respectively, to overall air exposure of $52.5,13.5$ and $2.5 \%$ of the experimental period (Lee 1989a). The experiment was started in early September 1987 and 3 replicate bags were retrieved for each inundation frequency on 6 occasions $(2,4,8,12,16$ and $24 \mathrm{wk}$ ) ending in late February 1988. Mud surface temperatures at the 3 stations were recorded by maximum-minimum thermometers.

The litter bags retrieved after specific decomposition periods were put into individual polythene bags. Superficial mud was cleared with distilled water and the bags stored at $-20^{\circ} \mathrm{C}$ if not processed immediately. Residual leaf fragments were carefully picked from the individual compartments, washed, and dried at $40^{\circ} \mathrm{C}$ on pre-weighed aluminium foil. The weight of the leaf fragments was then recorded to the nearest $\mathrm{mg}$ after drying for $48 \mathrm{~h}$. All animals washed from the bags were collected on a $500 \mu \mathrm{m}$ sieve, identified, and counted.

The ash-free dry weights (AFDW) of individual leaf remnants were estimated by ashing a weighed subsample (ca $100 \mathrm{mg}$ ) at $500^{\circ} \mathrm{C}$ for $3 \mathrm{~h}$, after drying for $48 \mathrm{~h}$ at $105^{\circ} \mathrm{C}$. Remaining leaf fragments were then pooled for each bag, ground and analyzed for levels of total organic carbon (wet oxidation by acid dichromate) and total organic nitrogen (Kjeldhal digestion and semi-microdistillation) (Allen et al. 1986). From these, the $C: N$ ratios at various stages of decomposition were calculated.

Data analyses: Changes in AFDW remaining (\%) of the 2 litter types at the 3 inundation levels were fitted to a simple negative exponential model (Olson 1963) in order to compare the relative rates of decomposition. Mean percentage initial AFDW figures were log-transformed and regressed with elapsed time (d). The slope of the linear equation gave the decomposition rate constant $(k)$. The half-life time $\left(t_{1 / 2}\right)$ was calculated from (ln 2)/k. Differences in decomposition rates for the inundation classes were compared by a 1-way ANOVA of the \% AFDW remaining data (after angular transformation) at various exposure periods.

Since the 3 stations experienced differences in both temperature and inundation regimes, attempts were made to differentiate the effects of the 2 factors. To equilibrate the effects of the temperature factor, the parameter $\mathrm{D}^{\circ}$, which incorporates both time and temperature, was employed. $\mathrm{D}^{\circ}$ was defined as the product of elapsed time in days and the average temperature during the time interval (Böetius 1962), as obtained from the mean of the maximum and minimum temperatures. Plots of $\%$ initial AFDW against cumulative $D^{\circ}$ for the 3 stations enable the decomposition rates to be compared for the 3 inundation classes at the same cumulated $\mathrm{D}^{\circ}$ value

Similarly, the effects of inundation were made constant by plotting the changes in AFDW of the leaves at the 3 stations against cumulative immersion time. This allows the effects of temperature differences on decomposition rates to be compared for the same amount of cumulative inundation time.

Export of litter: The amount of litter exported from the reed beds was taken as the average amount of litter collected at a net $(1 \mathrm{~cm}$ mesh size) across the sluice gate during 9 draining occasions. The materials collected were then washed and dried at $80^{\circ} \mathrm{C}$ for $48 \mathrm{~h}$ and the dry weight recorded.

Spread of Phragmites communis. The development of the reed beds in the pond was followed by serial air photographs starting from 1970. Patches of P. communis can be distinguished from mangroves by their much lighter shade in the prints. The areal spread of the reed beds could then be traced.

\section{RESULTS}

\section{NAPP estimation}

The average standing biomass of the 4 aboveground components and the total aboveground biomass of Phragmites communis stands are shown in Fig. 1. Total aboveground living biomass of $P$. communis varied between a May 1986 minimum of $693.4 \pm 212.4$ and an

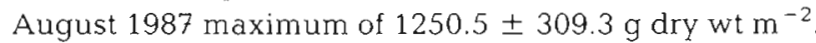
Biomass figures in individual plots varied from 299.0 to $2076.4 \mathrm{~g}$ dry $w \mathrm{t} \mathrm{m}^{-2}$. Table 1 summarizes the energy values of the various components of $P$. communis. The values generally lie within the range for the species as

Table 1. Phragmites communis. Mean energy values $\left(\mathrm{kcal} \mathrm{g}^{-1}\right.$ dry wt $\pm \mathrm{SD}$ ) of various components

\begin{tabular}{|ll|}
\hline Component & Energy value \\
\hline Green leaves & $4.032 \pm 0.079$ \\
Brown leaves & $3.937 \pm 0.224$ \\
Flower plumes & $3.889 \pm 0.087$ \\
Rhizomes & $3.580 \pm 0.140$ \\
Green shoot & $3.634 \pm 0.143$ \\
Brown shoot & $3.919 \pm 0.163$ \\
\hline
\end{tabular}



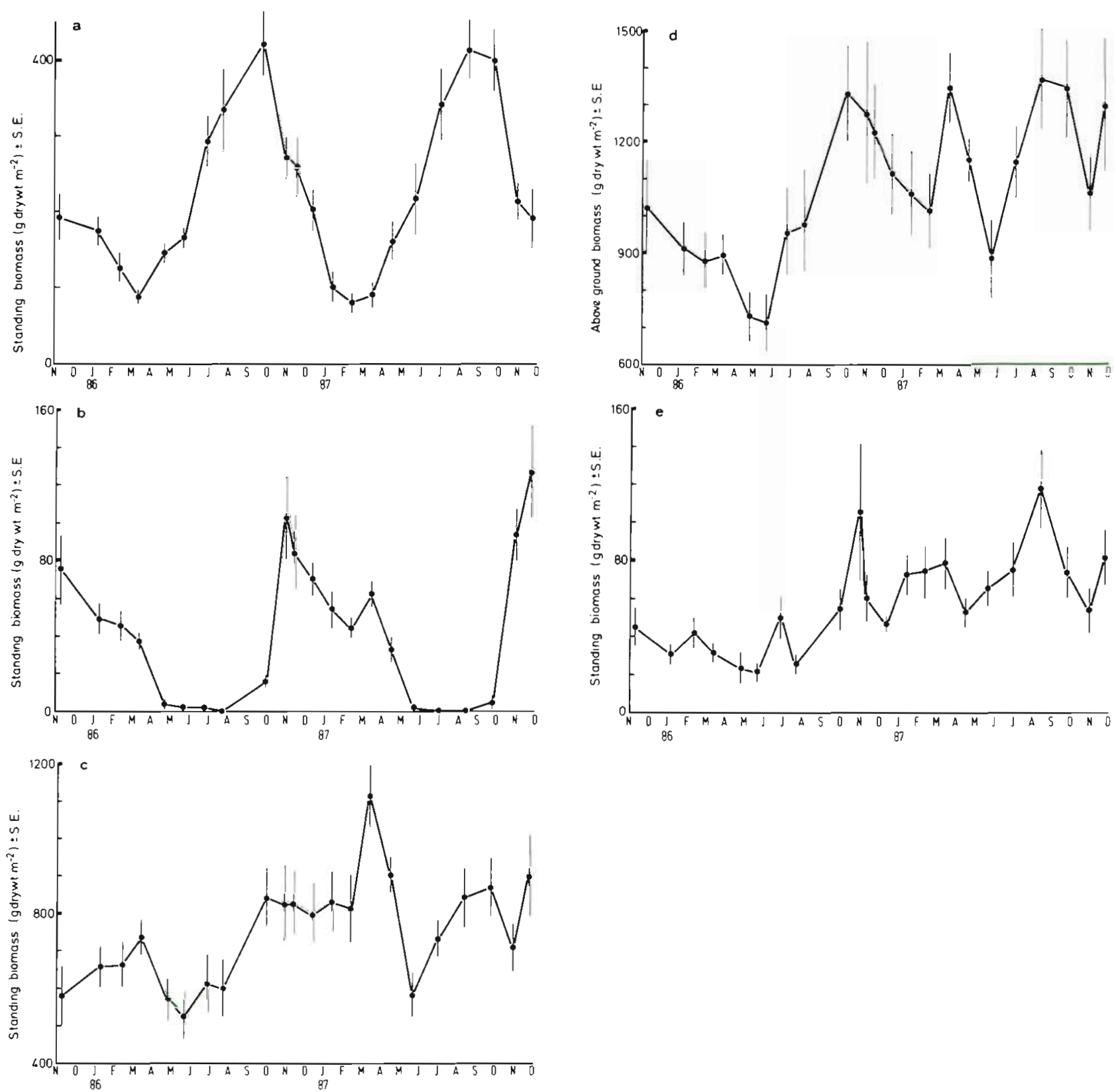

Fig. 1. Phragmites communis. Seasonal changes in the standing crop biomass ( $g$ dry $w \mathrm{~m}^{-2}$ ) of the various aboveground components. (a) Green leaves; (b) flower plumes; (c) shoots; (d) total biomass; and (e) dead leaves

summarized by Handoo et al. (1988). When adjusted for the relative contributions of the components, these biomass figures respectively represent values of (a) range for monthly means: $2.586 \times 10^{7}$ to $5.551 \times 10^{7}$ $\mathrm{kcal} \mathrm{ha}^{-1}$ and (b) range for individual plots: $1.119 \times 10^{7}$ to $7.755 \times 10^{7} \mathrm{kcal} \mathrm{ha}^{-1}$.

Highly seasonal growth is suggested by the variations in standing biomass of different components. Variations in the standing biomass of green leaves and flower plumes showed respective peaks in summer (August-September) and winter (NovemberDecember) (Fig. 1a,b). Variations in other components were less seasonal. Shoot biomass, nevertheless, showed consistent minimum values in May-June declining from peak values in March, corresponding to a large-scale die-back of the previous season's growth (from May-June until March) (Fig. 1c). This pattern can be recognised also for the total aboveground biomass, despite wide variation among the plots (Fig. 1d). The biomass of dead components was variable, but tended to reach maximum values in early winter (October-November).

Values of $r$, the daily proportional loss of dead material, averaged $0.0097 \mathrm{~d}^{-1}$ for the pooled data and 
mean values varied from 0.0048 to $0.031 \mathrm{~d}^{-1}$ for the 8 plots. Mean values for the individual plots were used in the estimation of $d_{d}$ for the particular site.

The average NAPP calculated from the modified Wiegert \& Evans (1964) method was $2198.3 \pm 416.7 \mathrm{~g}$ dry wt $\mathrm{m}^{-2} \mathrm{yr}^{-1}\left(21.98 \pm 4.17 \mathrm{tha}^{-1} \mathrm{yr}^{-1}\right)$. Green leaves and culms of Phragnites communis have similar percent organic contents, being respectively $86.2 \pm 2.4$ and $87.2 \pm 1.7 \%$. Thus, using an average value, the productivity figure was equivalent to $1906.5 \pm 361.4 \mathrm{~g}$ AFDW m ${ }^{-2} \mathrm{yr}^{-1}\left(19.06 \pm 3.61 \mathrm{t}_{\text {AFDW ha }}^{-1} \mathrm{yr}^{-1}\right)$. Productivity averaged 1961.1 \pm 239.7 (1711.1 \pm 209.2 AFDW) and $2469.4 \pm 410.7$ (2145.5 \pm 358.3 AFDW) $g$ dry wt $\mathrm{m}^{-2} \mathrm{yr}^{-1}$ respectively for 1986 and 1987 , indicating an increase of $25.9 \%$ in the second year.

A weighted energy value for living Phragnites communis biomass is $3.75 \mathrm{kcal} \mathrm{g}^{-1}$, assuming average respective mean annual contributions of 70,25 and $5 \%$ of the biomass production from the culm, leaves and flower components. Using this conversion factor, NAPP in energetic terms would be equivalent to respectively $7.35 \pm 0.90 \times 10^{7}$ and $9.25 \pm 1.54 \times 10^{7} \mathrm{kcal} \mathrm{ha}^{-1} \mathrm{yr}^{-1}$ for 1986 and 1987 . The average value would be $8.24 \pm$ $1.56 \times 10^{7} \mathrm{kcal} \mathrm{ha}^{-1} \mathrm{yr}^{-1}$. With an annual global radiation at $1.18 \times 10^{10} \mathrm{kcal} \mathrm{ha}^{-1} \mathrm{yr}^{-1}$ and assuming photosynthetically active radiation to be $40 \%$ of the total radiation, $P$. communis has a production efficiency of $1.75 \%$.

Pooled data for gei wai 18 gave yearly NAPP of respectively 1165.5 (1016.9 AFDW) and 1351.8 (1179.4 AFDW) $\mathrm{g}$ dry $w \mathrm{w} \mathrm{m}^{-2} \mathrm{yr}^{-1}$. The average was $1258.6 \mathrm{~g}$ dry wt $\mathrm{m}^{-2} \mathrm{yr}^{-1}\left(1098.2 \mathrm{~g} \mathrm{AFDW} \mathrm{m}^{-2} \mathrm{yr}^{-1}\right)$. Asynchrony in growth and production between the sites as well as different site-specific decomposition losses probably caused the underestimation when the data were pooled in the calculation.

The belowground biomass accounted for an average of $31.2 \pm 13.4 \%$ of the aboveground biomass. Thus, total net primary productivity calculated from this conversion factor is $2884.2 \pm 546.7 \mathrm{~g}$ dry $\mathrm{wt} \mathrm{m}^{-2} \mathrm{yr}^{-1}$, assuming equal turnover rates for the aerial and belowground components. This assumption probably creates an overestimation, as rhizomes of Phragmites communis are perennial (Haslam 1972). Decomposition of the belowground components might also create anomalous figures, but Hackney \& de la Cruz (1980) suggested that such a rate is probably too low to significantly affect estimations of net total primary productivity. The average energy value of the rhizomes was 3.58 $\pm 0.14 \mathrm{kcal} \mathrm{g}^{-1}$ (Table 1 ). This gives an energy equivalent for total net primary production of $1.07 \times 10^{8} \mathrm{kcal}$ ha ${ }^{-1} \mathrm{yr}^{-1}$.

The production of detritus from Phragmites communis also varied greatly with the method of measurement. If all materials produced in the previous year are assumed to be dead in the coming growing season, then the amount of detritus entering the pond would be equal to $P_{\mathrm{N}}$. In contrast, if only positive changes together with loss in dead material biomass was counted (not assuming any turnover rate, i.e. $\sum(\delta \mathrm{D}+$ $\mathrm{d}_{\mathrm{d}}$ ), then a much lower value would be obtained. The average ratio of $\sum(\delta B) / P_{N}$ was $0.77 \pm 0.08$. Since $B_{\min }$ of $P$. communis stands were much higher than 0 , death and regrowth probably occurred simultaneously at the stands such that $\sum\left(\delta D+d_{d}\right)$ gave more realistic figures for detritus production. The value averaged $504.9 \pm$ $212.7 \mathrm{~g}$ dry wt $\mathrm{m}^{-2} \mathrm{yr}^{-1}$. This is equivalent to an energy input of $1.98 \pm 0.84 \times 10^{7} \mathrm{kcal} \mathrm{ha}^{-1} \mathrm{yr}^{-1}$, using an average energy conversion factor of $3.928 \mathrm{kcal} \mathrm{g}^{-1}$ for dead $P$. communis culms and leaves.

\section{Litter dynamics}

\section{Decomposition rates at different inundation frequencies}

A summary of the temperature profiles, variations in the cumulative day-degree and cumulative inundation time values can be found in Lee (1989a). Basically, the upper station experienced the most extreme temperature fluctuations, from 1 to $48^{\circ} \mathrm{C}$ during the study period. The $\mathrm{M}$ and $\mathrm{L}$ stations had generally narrower temperature fluctuations.

The decomposition of the litter at the 3 elevations followed dissimilar patterns (Fig. 2). Phragmites communis litter showed rapid initial loss of about $40 \%$ of the original AFDW in the first $4 \mathrm{wk}$ at all stations.

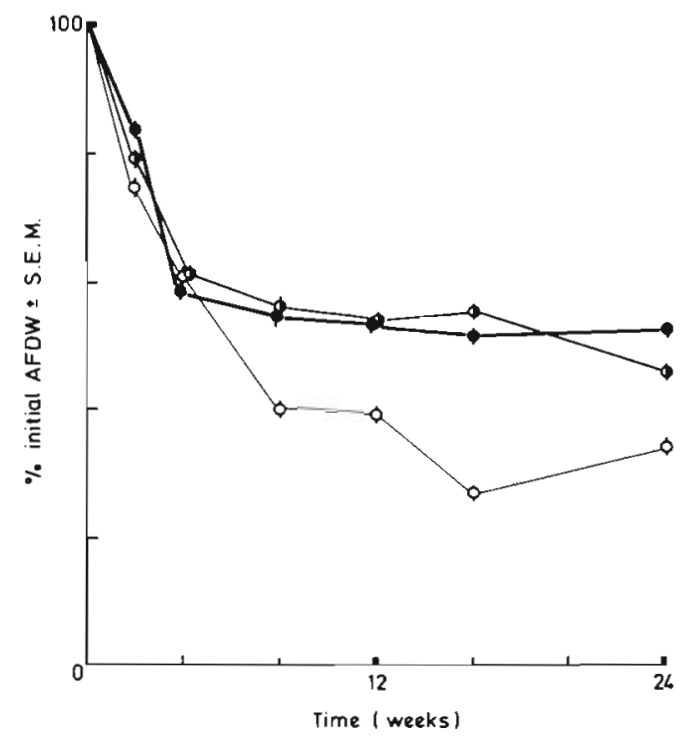

Fig. 2. Phragmites communis. Changes in ash-free dry weight (AFDW) of leaf litter decomposed at the U (O), M (o) and L (•) stations 

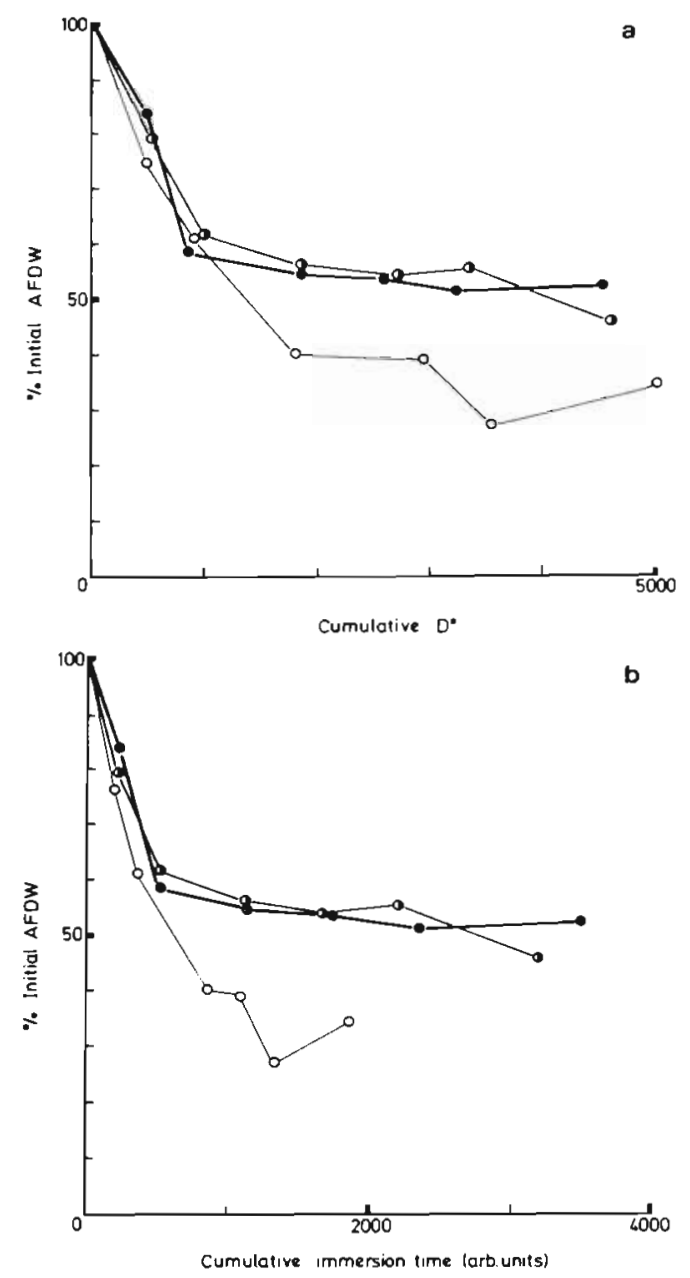

Fig. 3. Phragmites communis. Changes in AFDW plotted against (a) cumulated day-degrees $\mathrm{D}^{\circ}$; and (b) cumulated immersion time I. Station symbols as in Fig. 2

Thereafter, rates at the $\mathrm{L}$ and $\mathrm{M}$ stations leveled off to almost insignificant values such that on average $52.7 \pm$ 8.1 and $46.1 \pm 5.0 \%$ of the initial AFDW remained after $24 \mathrm{wk}$ field exposure. In contrast, the loss in AFDW at the $U$ station was persistent throughout the experimental period, although the rate was signifi- cantly slower after the 8 th week. On average $34.6 \pm$ $10.6 \%$ of the initial AFDW remained for the $U$ set after $24 \mathrm{wk}$. One-way ANOVA on AFDW remaining at the 3 levels at various times showed that $F$ values for the 8 , 16 and $24 \mathrm{wk}$ exposure sets were all significant at $\mathrm{p} \leq$ $0.0001 ; F_{2,41}=8.11$ for the 4 wk set, $p=0.0011$. AFDW remaining at the $U$ station was significantly $(p<0.01)$ less than those at the $M$ and $L$ stations from the 4 th week onwards, indicating an overall faster decomposition rate at that elevation.

Percentage initial AFDW variations for the litter are plotted against cumulative $\mathrm{D}^{\circ}$ in Fig. 3. Phragmites communis litter decomposed rapidly at the most exposed (U) site. The rate of AFDW loss for the $U$ set was much exaggerated when plotted against cumulative inundation, suggesting that decomposition rate of $P$. communis litter was greatly enhanced at this degree of exposure $(52.5 \%$ total time).

The $\%$ data were fitted to the negative exponential model to allow comparisons between the relative rates of decay. Table 2 summarizes the regression coefficients for the equations describing decomposition at different elevation.

Decomposition at the $U$ and $M$ stations could be described by the negative exponential model ( $\mathrm{p}<$ $0.05)$. Samples at the L station could not be aclequately explained by the negative model, significance of the regression $r$ being 0.1352 . Values of the decomposition rate constant $\mathrm{k}$ so obtained were lower than the average r value obtained from the paired plots $\left(0.0097 \mathrm{~d}^{-1}\right)$. Half-life times $\left(\mathrm{t}_{1 / 2}=0.693 / \mathrm{k}\right)$ calculated from the decomposition constants were 130.5, 251.1 and 315.0 d.

Regression using cumulative day-degree $\left(D^{\circ}\right)$ and cumulative immersion time (I) as the predictors for remaining AFDW yielded better fits for the negative exponential model, as evident from the increase in significance levels (Table 2). The best predictor for the $\mathrm{U}$ station was cumulative immersion time while cumulative $\mathrm{D}^{\circ}$ predicted decomposition profiles for the $M$ and $L$ stations with greatest accuracy. Multiple regression models using $D^{\circ}$ and $I$ as predictors gave

Table 2. Phragmites communis. Values of the decomposition constant $\mathrm{k}\left(\mathrm{d}^{-1}\right)$ from regression equations describing changes in AFDW litter and predictors of (a) time, (b) cumulative day-degrees $D^{\circ}$, (c) cumulative immersion time I, and (d) $D^{\circ}$ and $I_{1}$ at the 3 elevations, based on the negative exponential model. Significance levels ( $p$ ) indicated in brackets. For case (d), the predictor(s) included by stepwise forward selection is indicated

\begin{tabular}{|c|c|c|c|c|}
\hline Sample & Time & $\mathrm{D}^{\circ}$ & I & $\mathrm{D}^{\circ}$ and I \\
\hline Upper & $\begin{array}{l}0.00531 \\
(0.0476)\end{array}$ & $\begin{array}{l}0.00018 \\
(0.0368)\end{array}$ & $\begin{array}{l}0.00052 \\
(0.0249)\end{array}$ & $\begin{array}{ll}I_{1} & 0.00052 \\
& (0.0249)\end{array}$ \\
\hline Middle & $\begin{array}{l}0.00276 \\
(0.0227)\end{array}$ & $\begin{array}{l}0.00011 \\
(0.0170)\end{array}$ & $\begin{array}{l}0.00014 \\
(0.0196)\end{array}$ & 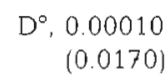 \\
\hline Lower & $(>0.2)$ & $(>0.2)$ & $(>0.2)$ & $\begin{array}{r}D^{\circ}, 0.00009 \\
(0.0881)\end{array}$ \\
\hline
\end{tabular}




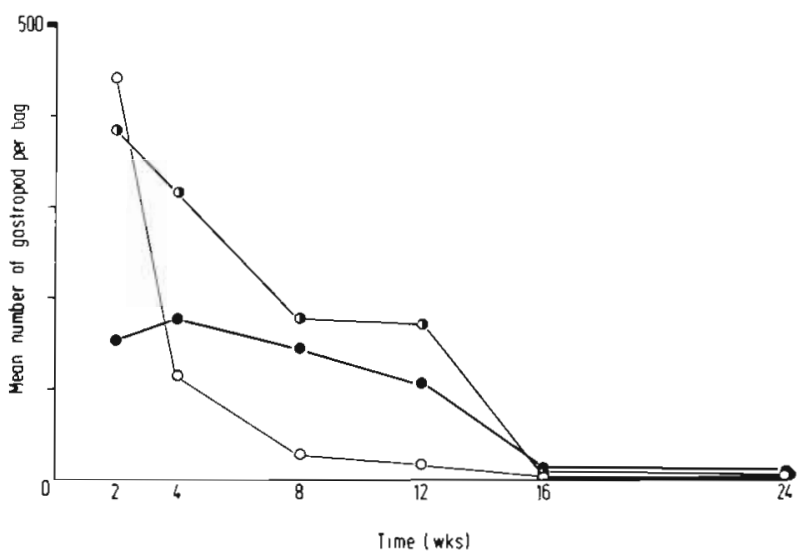

Fig. 4. Mean number of live gastropods in each $25 \times 25 \mathrm{~cm}$ litter bag at the 3 elevations. Station symbols as in Fig. 2

only the more important variable indicated by the single predictor equations.

When $\mathrm{D}^{\circ}$ was used as the predictor, values of $\mathrm{k}$ indicated that decomposition rates at the stations followed the same order, i.e. $U>M>L$. This implies that for the same amount of $D^{\circ}$ elapsed, the cumulative loss of AFDW followed the above order. Phragmites communis litter decomposed at faster rates with increasing exposure.

Gastropods made up $>95 \%$ of the number of animals associated with the litter bags. Means and ranges of live gastropod numbers recorded for the litter bags at the 3 levels are depicted in Fig. 4. Snail densities were very high ( $\geq 400$ ind. per bag) initially at the $U$ and $M$ stations. Snail densities generally decreased with time but the time at which final low levels were reached differed between station elevations. Snail densities decreased to such levels by the 8th week at the U station, but similar declines were delayed until the 16th week for the $\mathrm{M}$ and $\mathrm{L}$ stations. The earlier decline of the gastropod population was probably related to desiccation stress and food exhaustion. Water level fell at Week 8 (Lee 1989a), mainly affecting the U station. For the $\mathrm{M}$ and L bags, large-scale snail mortality probably occurred only when the litter remaining in the bags failed to support the large population.

Variations in percent organic carbon and percent total nitrogen for the remaining litter are shown in Fig. 5. Decreases in the nutrient levels were effected over a longer period. The rate of loss of percent organic carbon was highest for the $U$ set, the value after $8 \mathrm{wk}$ being only $18.5 \%$. Decreases for the $M$ and $L$ sets continued at low rates throughout the experimental period. Values for the U, M and L sets were respectively 22, 25 and $29 \%$ (Fig. 5a).

Percent total nitrogen for Phragmites communis litter followed different patterns at the 3 elevations (Fig. 5b). The time taken to reach the highest $\% \mathrm{~N}$ value
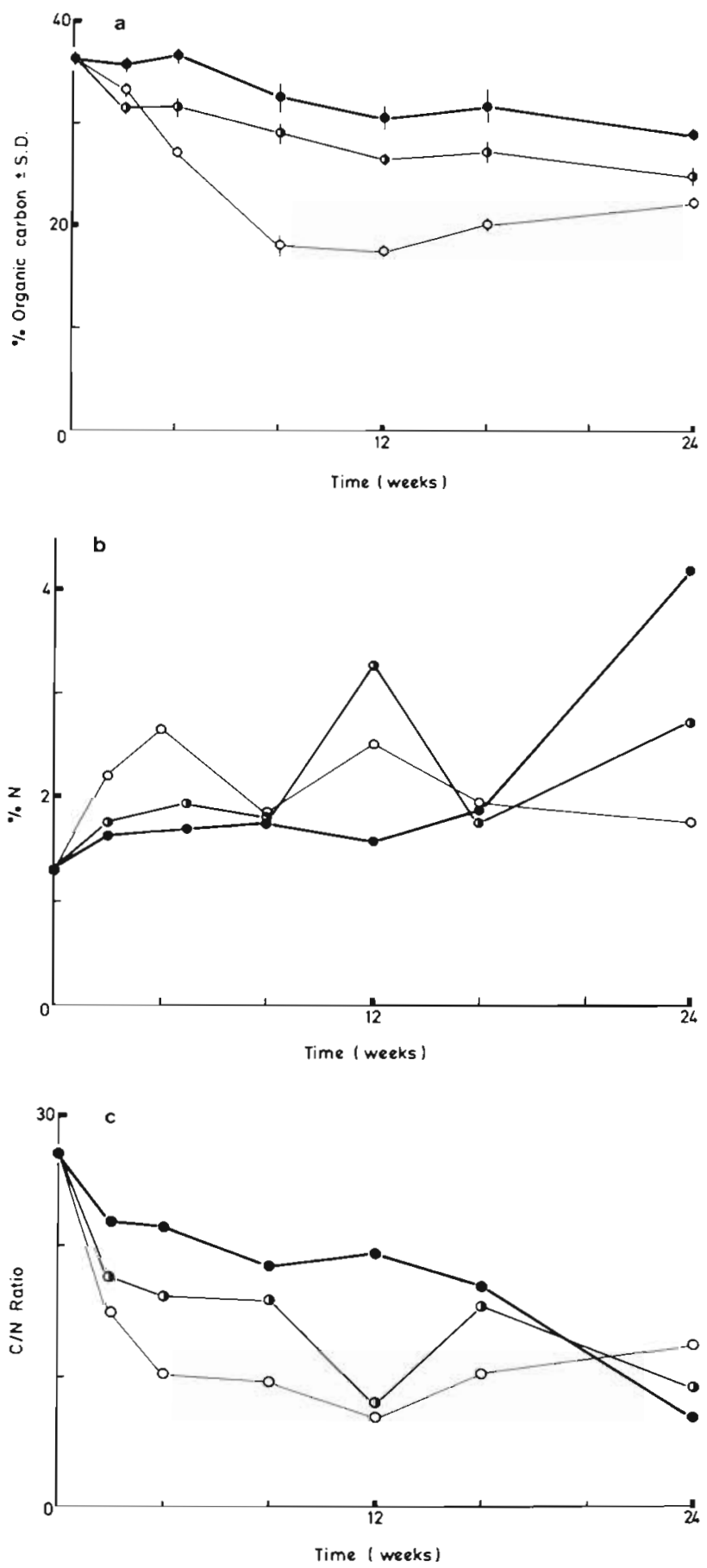

Fig. 5. Phragmites communis. Changes in (a) \% organic carbon; (b) \% organic nitrogen; and (c) C:N ratio in decomposing litter at the 3 elevations. Station symbols as in Fig. 2

increased with increasing inundation. Concentrations in the $U$ set doubled from 1.3 to $2.65 \%$ after $4 \mathrm{wk}$. Increases for the $\mathrm{M}$ and $\mathrm{L}$ sets were more moderate; the peak value of $3.25 \%$ for the $M$ set was attained at the 12 th week and the L set maintained a low constant level until rapidly increasing to the maximum of $4.15 \%$ by the 24 th week. 
C:N ratios (based on \% dry wt) for Phragmites communis litter maintained moderate decreases throughout the study period, decreasing from an initial value of 27.1 to between 7 and 12.5 at the 24 th week. Rates of decrease during the first 4 wk for the $M$ and $L$ sets, however, were high. The U set maintained high rates of decrease up to the 8 th week (Fig. 5c).

\section{Litter export}

Phragmites communis litter constituted $11.5 \pm 5.8 \%$ of the total dry weight of litter (mean $=257.1 \mathrm{~g}$ dry wt $\mathrm{d}^{-1}$ ) collected at the sluice net during draining operations. Litter from Kandelia candel made up the bulk of the rest. The export rate of $P$. communis litter was thus $29.6 \pm 18.3 \mathrm{~g} \mathrm{dry} \mathrm{t}^{-1}$, assuming one draining operation per day. This amount is equivalent to only $0.059 \%$ of the daily litter production in 1987, based on an areal coverage of $40 \%$ total gei wai area by $P$. communis. This, however, does not include fine POM production from in situ decomposition.

\section{Spread of Phragmites communis}

Establishment of Phragmites communis in the gei wai can be traced back to 1975 . Prior to this, $P$. communis was virtually non-existent and the plant community was typically mangrove-dominated. Landscape restructuring in 1975 resulted in large-scale mangrove cutting, followed by rapid colonization and spread of $P$. communis on the open substrate. Thereafter, areal coverage gradually increased. The second extensive spread occurred in 1987, with most of the open, elevated mud platforms colonised. The cover by $P$. communis increased from about $9.5 \%$ in 1985 to ca $40 \%$ in early 1988.

\section{DISCUSSION}

\section{Success of Phragmites communis}

NAPP estimates for marsh emergents (both fresh and salt water) range widely between ca 100 and $4000 \mathrm{~g}$ dry wt m $\mathrm{m}^{-2} \mathrm{yr}^{-1}$, but most records are around 1000 to $2000 \mathrm{~g}$ dry wt $\mathrm{m}^{-2} \mathrm{yr}^{-1}$ (Keefe 1972, Mason \& Bryant 1975, Linthurst \& Reimold 1978, Whigham et al. 1978, Gallagher et al. 1980, Brinson et al. 1981, Bradbury \& Grace 1983, Odum et al. 1984, Dame \& Kenny 1986 , Dame 1989). Nearly all estimates are, however, from temperate populations. Productivity figures calculated by different methods yield great differences, as demonstrated by Shew et al. (1981), Marinucci (1982), Pierce
(1983), Groenendijk (1984) and Houghton (1985). The above range of productivity figures was obtained from data mostly utilizing the method of maximum standing biomass. Although the use of non-destructive methods has been proposed by some researchers (e.g. Jackson et al. 1986), measurements of individual shoots often limit the affordable sample size. Of destructive methods, procedures accounting for decomposition loss (e.g. the Wiegert \& Evans method used in this study) probably give realistic estimates of NAPP (Linthurst \& Reimold 1978, Bradbury \& Grace 1983, Groenendijk 1984). Shew et al. (1981) and Dame (1989) recorded that, however, the Wiegert \& Evans method may overestimate NAPP and suggested that the method of Lominicki et al. (1968) (which is a modification of the original Wiegert \& Evans method) probably gives the best, but still slightly overestimated, value.

As mortality and growth of Phragmites communis probably occur simultaneously in the gei wai, and timing of these processes seems dependent on plotspecific environment, mean NAPP calculated from averaged individual plot values is probably more realistic than that obtained from pooled data. The maximum minus minimum biomass harvest method for estimation of local $P$. communis primary productivity is also invalidated by interstation variability.

NAPP of Phragmites communis in the gei wai increased from $1961.1 \pm 239.7$ in 1986 to $2469.4 \pm$ $410.7 \mathrm{~g} \mathrm{dry} \mathrm{wt} \mathrm{m}^{-2} \mathrm{yr}^{-1}$ in 1987 (25.9\% increase). The 1987 value is higher than most figures documented for marsh plants by Keefe (1972), Whigham et al. (1978) and Odum et al. (1984). The value is near the upper limit of the range reported for Phragmites (de la Cruz 1974, Hopkinson et al. 1978, Linthurst \& Reimold 1978 , Whigham et al. 1978, Howard-Williams \& Allanson 1981, Roman \& Daiber 1984, Bally et al. 1985, Schleyer \& Roberts 1987). The value is, however, very much lower than that reported by Hocking (1989) (129 $\mathrm{t}$ fresh wt ha $\mathrm{a}^{-1} \mathrm{yr}^{-1}$ ) since the dry weight was about $73 \%$ the fresh weight in the present study. One reason for this high NAPP for P. communis (mean $=2215.2 \mathrm{~g} \mathrm{~m}^{-2} \mathrm{yr}^{-1}$ ) at Mai Po may be the long growing season in subtropical Hong Kong. Keefe (1972) and Dame (1989) compared biomass and productivity of Spartina alterniflora along the Atlantic coast of the USA and concluded that both measures generally decreased with increasing latitude. Supportive comparative data for $P$. communis are lacking, as low latitude measurements are virtually non-existent.

Local growth conditions probably also control productivity and biomass values. High production of marsh plants is usually attributed to growth in nutrientrich substrates and water, and in the case of freshwater species, constant low water stress (Keefe 1972, Bradbury \& Grace 1983). In particular, Phragmites com- 
munis seems able to thrive in eutrophic conditions, with elevated standing biomass and NAPP in nutrientrich environments (Ho 1979, Granéli 1985, Ulrich \& Burton 1985, Dinka 1986, Hofmann 1986, Hocking 1989). Water in the gei wai is typically eutrophic, with high standing levels of nutrients (nitrate and phosphates), up to 16 and 10 ppm respectively (Lee 1988). Such nutrient levels may partly explain the high productivity of $P$. communis at Mai Po. During the 2 yr study period, increases in overall areal coverage and primary productivity of $P$. communis in gei wai 18 were evident. Haslam (1972) suggested use of aerial biomass, flowering shoot density, shoot height and basal diameter to assess performance of $P$. communis in different environments. The high maximum biomass of $1250.50 \mathrm{~g}$ dry $w \mathrm{t} \mathrm{m}^{-2}$, elevated NAPP of $>2000 \mathrm{~g}$ dry wt $\mathrm{m}^{-2} \mathrm{yr}^{-1}$, shoot height of $>2 \mathrm{~m}$ and density of $>50$ shoots $\mathrm{m}^{-2}$ all indicate that $P$. communis is well established in the nature reserve.

Success of the opportunistic Phragmites communis is enhanced by the setting and operation of the gei wai. Rapid accretion, landscape disturbance, infrequent salt water submergence and lack of competitors all promote growth and establishment of $P$. communis (Phillips 1987). Serial air photographs revealed that rapid spread of $P$. communis was always associated with landscape disturbance in the gei wai, e.g. removal of the endemic mangroves. Sediment trap data suggest an accretion rate in the gei wai of $1.7 \mathrm{~cm} \mathrm{yr}^{-1}$ (Lee 1988). Prior to 1987, substrate level in the gei wai was probably still low enough to reduce competitive ability (i.e. to restrict germination success and rhizome propagation), and extensive spread was checked. The water level regime in 1986 to 1988 only allowed inundation of the open mud flats for $<15 \%$ of the time (Lee 1988). The annual winter drawdown, a common operational practice, exposes large uncolonized mud flats during the seeding period (December to February) (Fig. 2). In summer, the flats are more frequently inundated but the depth is generally not sufficient $(<1 \mathrm{~m})$ to discourage rhizome propagation and shoot growth (Haslam 1972, Yamasaki \& Tange 1981). Conversely, the prevalent low summer salinities (0 to $15 \%$ ) also encourage shoot production. Seed germination in winter and vegetative propagation by rhizomes in summer are therefore facilitated on the exposed flats. Seed germination of $P$. communis is not hampered by salinities as high as $0.5 \mathrm{M} \mathrm{NaCl}$ (Waisel 1972) and the plant is able to withstand high soil salinities by sodium exclusion (Matoh et al, 1988). The facilitating environment of the gei wai becomes apparent when the community pattern is compared with seaward, tidally inundated, areas where $P$. communis is scarce.

Belowground productivity is seldom measured for wetland plants. Belowground components of Phrag- mites communis averaged $31.2 \pm 13.4 \%$ of the aboveground component, similar to that recorded by Kvet (1971) for the same species but much lower than those recorded for this and other salt marsh species on the American Atlantic coast (Good et al. 1982, Odum et al. 1984, Dame 1989). The extent that nutrients from senescent shoots are withdrawn to the rhizome probably affects nutrient release through decomposition and deserves closer examination.

\section{Litter dynamics}

Net production and detritus production by Phragmites communis is summarised in Fig. 6. With high productivity, $P$. communis functions as an important detritus source in the system. Whigham et al. (1978) and Odum et al. (1984) reviewed production and biomass data for freshwater wetlands of the north American Atlantic coast and both recorded that marshes dominated by Phragmites tended to have the highest peak standing crop values. Litter input from the $P$.

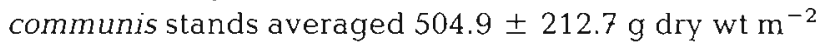
$\mathrm{yr}^{-1}$, equivalent to $45.6 \%$ of that from Kandelia candel, the other major macrophyte producer in the system (Lee $1989 \mathrm{~b}$ ). This value is also equivalent to $22.8 \%$ of the NAPP. Such a difference between NAPP and total litter production again suggests that turnover of aboveground parts for $P$. communis is far from unity, thus precluding the use of maximum biomass data for measurements of NAPP. From the ratio of mean NAPP to mean monthly standing aboveground biomass, the turnover of shoots and leaves of $P$. communis is calculated to be $2.20 \mathrm{yr}^{-1}$, which is close to that obtained for Spartina anglica in east England (Jackson et al. 1986). Litter export rate measured across the sluice channel is significantly less than the 15 to $20 \%$ value recorded by Jackson et al. (1986) for an S. anglica marsh. Thus, as with $K$. candel (Lee 1989b), the bulk of litter produced is recycled in situ. This is supported by the high average standing litter biomass recorded in the quadrats.

Standing litter biomass was lowest in summer (< $28 \mathrm{~g}$ dry wt $\mathrm{m}^{-2}$ ) but could reach about $120 \mathrm{~g}$ dry $\mathrm{wt}$ $\mathrm{m}^{-2}$ in late winter, i.e. between 0.28 and $1.20 \mathrm{t} \mathrm{ha}^{-1}$. Standing litter biomass in older stands is probably higher, as export from these is even less. The elevation of most stands above the general water level and the dense shoots probably effectively retain most litter in the stands.

As with Kandelia candel stands, turnover of accumulated Phragmites communis litter is slow. The rate of disappearance of $P$. communis litter estimated from the paired plots averaged $0.016 \pm 0.007 \mathrm{~d}^{-1}$, the range being 0.0048 to 0.0310 . Comparison of this reading with other reports is difficult as most past studies 


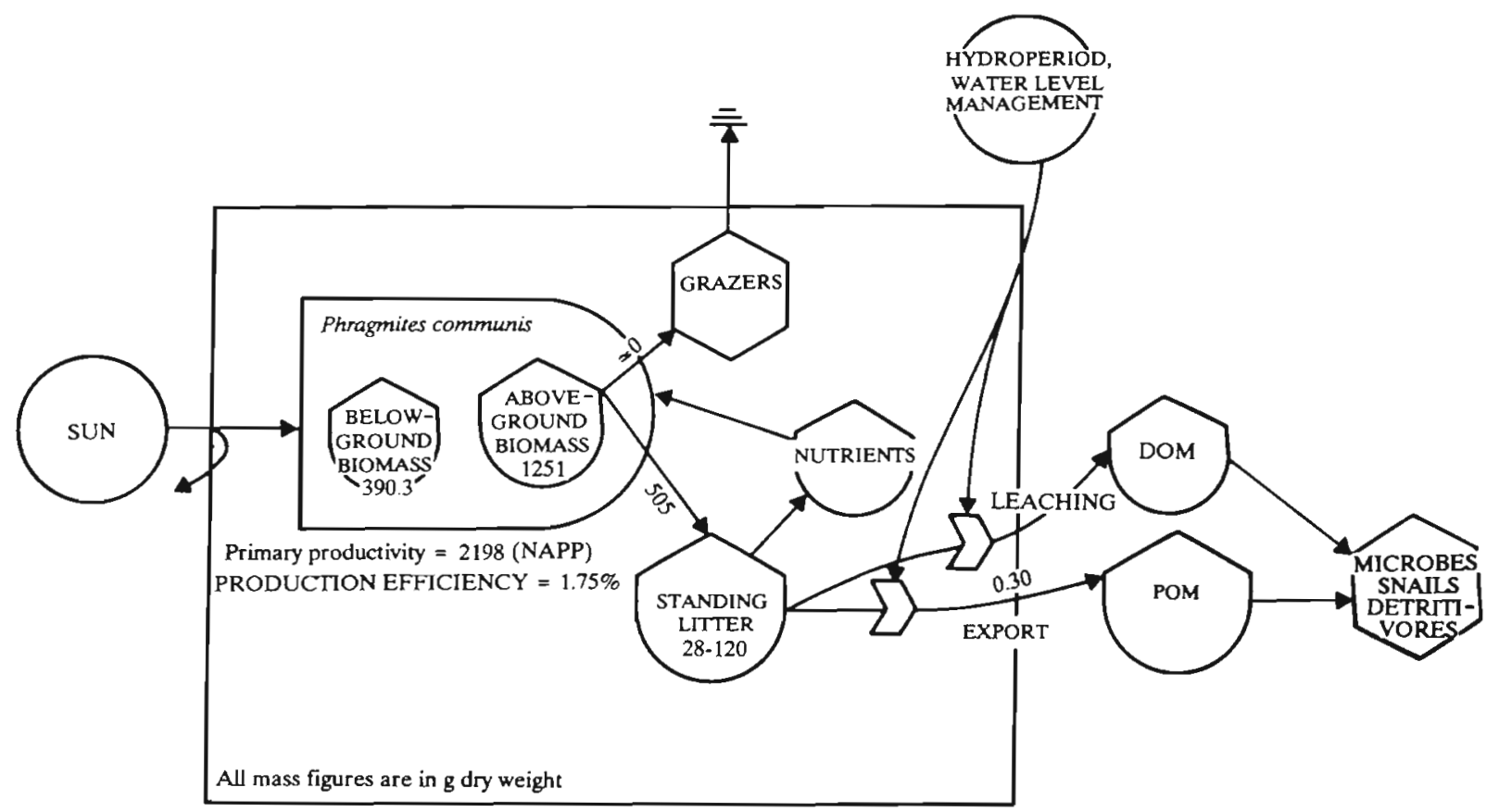

Fig. 6. Phragmites communis. Summary of net production and detritus dynamics in the gei wai, using the energy language of Odum (1983)

assume a negative exponential decay model for litter disappearance. The validity of this model is controversial in the heterogeneous estuarine environment (Linthurst \& Reimold 1978, Roberts et al. 1985). However, from the slow decomposition rates, probably only small percentages of NAPP are lost.

The bulk of litter produced by Phragmites communis is retained and decomposed in situ. Owing to inundation differences, different vertical zones in the gei wai probably have varying microclimates, e.g. moisture regime, temperature ranges, and also different faunal and microbial assemblages to effect decomposition. The possible differences in decomposition rates in various parts of the gei wai therefore influences detritus turnover in the system, as litter produced by the various sources is patchily distributed.

Working on mangrove litter decomposition in tropical Australia, Robertson (1988) argued that subtidal decomposition rates are faster because of a more constant environment for heterotrophs to participate in decomposition. While this may be generally true when subtidal rates are compared with rates recorded under more extreme physical fluctuations, e.g. near $100 \%$ exposure (Teal 1962, Heald 1971, Kirby \& Gosselink 1976, Odum \& Heywood 1978, Marinucci 1982, Twilley et al. 1986, Flores-Verdugo et al. 1987, Steinke \& Ward 1987), the dynamic nature of intermediate exposure levels may influence decomposition rate differently. In a parallel study on Kandelia candel litter decomposition at the same sites, leaves decomposed fastest at the $M$ station (Lee 1989a). In the present study, however,
Phragmites communis litter decomposed fastest at the U station, probably a result of increased snail grazing activities on phylloplane algae. Polunin (1982) recorded increased bacterial activities on litter grazed by Planorbis carinatus when compared with ungrazed controls. The phylloplane algal growth is also responsible for the apparent low C:N ratios for the decaying $P$. communis litter, as the range of values is typical of blue-greens and microbes (Valiela 1984). This then illustrates the importance of secondary factors such as algal growth arising from basic attributes (e.g. texture and toughness, chemical composition) of the original litter on decomposition rate.

\section{Management implications}

Established Phragmites communis populations are highly resilient. Periodic burning and harvesting do not necessarily reduce the vigor but in some cases increase subsequent growth (Haslam 1972, Van der Toorn \& Mook 1982, Björndahl 1985, Thompson \& Shay 1985). The perennial rhizome and the clonal growth of shoots help reorientation of food reserves during stressful periods (Davis \& Briggs 1986). Uncontrolled spread of $P$. communis, though providing massive detritus input into the gei wai through high productivity, depletes the gei wai of open water area (to $<35 \%$ in the study pond) such that optimal habitat heterogeneity for waterfowl cannot be maintained (Kaminski \& Prince 1981). Due to the limited dispersal potential of Kandelia 
candel in the gei wai environment, it is foreseeable that any future disturbance to the $K$. candel community will result in further replacement by $P$. communis. This actually occurred in about 1980, when the northern gei wais were changed into freshwater fish ponds by blocking the sluice gates. Constant submersion by relatively deep freshwater killed the mangroves, and $P$. communis spreed rapidly to dominate the ponds. In 1986, mangroves in 2 of the gei wais were cut and large-scale earth-moving work initiated. Again, the bare mud was rapidly colonized by the opportunistic $P$. communis and repeated effort has had to be spent on its control.

While Kandelia candel suffers about $10 \%$ foliage loss through insect grazing (Lee in press), Phragmites communis suffers negligible loss apart from short seasonal blooms of sucking insects (e.g. aphids) when alive. Seasonal dieback of aerial parts and subsequent decomposition is thus the major turnover pathway of $P$. communis production. With gradual elevation of the substrate level and the parallel areal spread of the species, large-scale litter accumulation results. Moderate enrichment by $P$. communis litter fragments may attract macrobenthic invertebrate colonisation through improving sediment texture and food provision (Lee 1988). Massive accumulation of litter at the $P$. communis beds, however, probably causes anaerobic condition to dominate, preventing the establishment of detritivore communities and exacerbating accretion rate (Schleyer \& Roberts 1987), all demanding extra management efforts to control. Growth of $P$. communis at sites with little litter export can, however, be selflimiting as a thick litter layer apparently suppresses shoot production (Granéli 1989). Probably related to joint effects of large amounts of organic matter accumulated and phytoplankton respiration, dissolved oxygen levels in the gei wai can become anoxic $10 \mathrm{mg}$ $\mathrm{I}^{-1}$ ) in summer nights (Lee 1988). Nevertheless, as shown in the decomposition experiment, growth of phylloplane algae on $P$. communis leaf litter provides a readily useable carbon source to grazing macroinvertebrates.

Schleyer \& Roberts (1987) suggested anaerobic conditions in Phragmites australis beds can be ameliorated by oxygenation. This can be an expensive operation and may deter waterfowl from using the habitat. Traditional control methods include prescribed cutting and burning (Haslam 1972, Mook \& Van der Toorn 1982). Burning of large reed beds may affect other wildlife in the reserve, and requires a long drying period before the burning to make it effective (Van der Toorn \& Mook 1982). However, more effective natural control of $P$. communis growth in the reserve may be planned according to the life cycle of the species. Manual clipping should be performed in autumn before the seeds are set. Cutting at this time also removes the peak biomass and allows a long exposure period of the rhizomes to relatively saline $(>20 \%$ ) water and will probably reduce the vigor of the subsequent regrowth. The biomass so harvested may be returned to the pond, spread temporally and spatially, to moderate detritus availability. For long-term control, occasional dredging would be necessary to lower the substrate level in order to restrict successful colonisation both by seed dispersal and rhizome propagation.

Acknowledgements. This work was supported by a John Swire Scholarship in Wetland Ecology administered by World Wide Fund For Nature Hong Kong. I thank Prof. B. Morton and the reviewers for their suggestions.

\section{LITERATURE CITED}

Allen, S. E., Grishaw, H. M., Rowland, A. P. (1986). Chemical analysis. In: Moore, P. D., Chapman, S. B. (eds.) Methods in plant ecology. Blackwell Scientific Publications, Oxford, p. 285-344.

Bally, R., McQuaid, C. D., Pierce, S. M. (1985). Primary productivity of the Bot River Estuary, South Africa. Trans. R. Soc. S. Afr. 45: 333-345

Björndahl, G. (1985). Influence of winter harvest on stand structure and biomass production of the common reed, Phragmites australis (Cav.) Trin. ex. Steud. in Lake Takern, southern Sweden. Biomass 7: 303-319

Böetius, I. (1962). Temperature and growth of Mytilus edulis (L.) from the Northern Harbour of Copenhagen (The Sound). Medd. Komm. Danm. Fisk. Hogavunders, Kopen., N. S. $3: 339-346$

Bradbury, I. K., Grace, J. (1983). Primary production in wetlands. In: Gore, A. J. P. (ed.) Ecosystems of the world. 4A. Mires, swamp, bog, fen and moor. Elsevier Scientific Publishing Company, Amsterdam, p. 285-310

Brinson, M. M., Lugo, A. E., Brown, S. (1981). Primary productivity, decomposition and consumer activity in freshwater wetlands. Ann. Rev. Ecol Syst. 12: 123-161

Cholik, F., Poernomo, A. (1987). Development of aquaculture in mangrove areas and its relationship to the mangrove ecosystem. F.A.O. Rep. 370 (Suppl.) 93-104

Clayton, W. D. (1968). The correct name of the common reed. Taxon 17: 168-169

Dame, R. F. (1989). The importance of Spartina alterniflora to Atlantic coast estuaries. CRC critical Rev. Aquat. Sciences 1: $639-660$

Dame, R. F., Kenny, P. D. (1986). Variability of Spartina alterniflora production in the euhaline North Inlet Estuary. Mar. Ecol. Prog. Ser. 32: 71-80

Davis, A. N., Briggs, T L. (1986). Dispersion pattern of aerial shoots of the common marsh reed Phragmites australis (Poaceae). Rhodora 88: 325-330

de la Cruz, A. A. (1974). Primary productivity of coastal marshes in Mississippi. Gulf Res. Rep. 4: 351-356

Dinka, M. (1986). The effect of mineral nutrient enrichment of Lake Balaton on the common reed (Phragmites communis). Folia Geobot. Phytotaxon. 21 65-84

Flores-Verdugo, F. J., Day, J. W., Jr., Briseño-Dueñas, R. (1987). Structure, litter fall, decomposition, and detritus dynamics of mangroves in a Mexican coastal lagoon with an ephemeral inlet. Mar. Ecol. Prog. Ser. 35: 83-90 
Galinato, M. I., van der Valk, A. G. (1986). Seed germination traits of annuals and emergents recruited during drawdowns in the Delta Marsh, Manitoba, Canada. Aquat. Bot. 26: $89-102$

Gallagher, J. L., Reimold, R. J., Linthurst, R. A., Pfeiffer, W. J. (1980). Aerial production, mortality, and mineral accumulation-export dynamics in Spartina alterniflora and Juncus roemerianus plant stands in a Georgia salt marsh. Ecology 61: 303-312

Good, R. E., Good, N. F., Frasco, B. R. (1982). A review of primary production and decomposition dynamics of the belowground marsh component. In: Kennedy, V. S. (ed.) Estuarine comparisons. Academic Press, New York, p. $139-157$

Granéli, W. (1985). Biomass response after nutrient addition to natural stands of reed, Phragmites australis. Verh. int. theor. angew. Limnol. 22: 2956-2961

Granéli, W (1989). Influence of standing litter on shoot production in reed, Phragmites australis (Cav.) Trin. ex Steudel. Aquat. Bot. 35: 99-110

Groenendijk, A. M. (1984). Primary production of four dominant salt-marsh angiosperms in the SW Netherlands. Vegetatio 57: 143-152

Hackney, C. T., de la Cruz, A. A. (1980). In situ decomposition of roots and rhizomes of two tidal marsh plants. Ecology 61: 226-231

Handoo, J. K., Saraf, N., Kaul, V. (1988). Energy content and ecological efficiency of macrophytes in Dal Lake, Kashmir Arch. Hydrobiol. 111: 351-367

Haslam, S. M. (1972). Biological flora of the British Isles Phragmites communis Trin. J. Ecol. 60: 585-610

Heald, E.J. (1971). The production of organic detritus in a South Florida estuary. Tech. Bull. Sea Grant Progm. Univ. Miami 6: 1-110

Ho, Y. B. (1979). Shoot development and production studies of Phragmites australis (Cav.) Trin. ex Steudel in Scottish lochs. Hydrobiol. 64: 215-222

Hocking, P. J. (1989). Seasonal dynamics of production, and nutrient accumulation and cycling by Phragmites australis (Cav.) Trin. ex Steudel in a nutrient-enriched swamp in inland Australia. I. Whole plants. Aust. J. mar. Freshwat. Res. 40: 421-444

Hofmann, V. K. (1986). Growth characteristics of reed (Phragmites australis [Cav.] Trin. ex Steudel) in filter-beds loaded with sewage sludge. Arch. Hydrobiol. 107: 385-409

Hopkins, C. S., Gosselink, J. G., Parrondo, R. T (1978) Aboveground production of seven marsh plant species in coastal Louisiana. Ecology 59: 760-769

Houghton, R. A. (1985). The effect of mortality on estimates of net above-ground production by Spartina alterniflora Aquat. Bot. 22: 121-132

Howard-Williams, C.. Allanson, B. R. (1981). An integrated study on littoral and pelagic primary production in a southern African coastal lake. Arch. Hydrobiol. 92 $507-534$

Jackson, D., Long, S. P., Mason, C. F. (1986). Net primary production, decomposition and export of Spartina anglica on a Suffolk salt-marsh. J. Ecol. 74: 647-662

Kaminski, R. M., Prince, H. H. (1981). Dabbling duck and aquatic macroinvertebrate responses to manipulated wetland habitat. J. WildI. Mgmt 44:1-15

Keefe, C. W. (1972). Marsh production: a summary of the literature. Contr. mar. Sci. Univ. Tex. 16: 163-181

Kirby, C. J., Gosselink, J. G. (1976). Primary production in Lousiana Gulf coast Spartina alterniflora marsh. Ecology 57: $1052-1059$

Kvet, J. (1971). Growth analysis approach to the production ecology of reedswamp plant communities. Hydrobiologia 12: $15-40$

Lee, S. Y. (1988). The ecology of a tidal shrimp pond in Hong Kong, the production and fate of macrodetritus and implications for manacrement. Unpublished Ph. D. thesis, University of Hong Kong, Hong Kong

Lee, S. Y (1989a). The importance of sesarminae crabs (Chiromanthes spp.) and inundation frequency on mangrove (Kandelia candel (L.) Druce) leaf litter turnover in a Hong Kong tidal shrimp pond mar. J. exp. mar. Biol. Ecol 131: $23-43$

Lee, S. Y (1989b). Litter production and turnover of the mangrove Kandelia candel (L.) Druce in a Hong Kong tidal shrimp pond. Estuar. coast. Shelf Sci. 29: 75-87

Lee, S. Y (in press). Herbivory as an ecological process in a Hong Kong mangal. J. trop. Ecol

Linthurst, R. A., Reimold, R. J. (1978). Estimated primary productivity for selected estuarine angiosperms in Maine Delaware, and Georgia. Ecology 59: 945-955

Lomnicki, A., Bandola, E., Janowska, K. (1968). Modification of the Wiegert-Evans method for estimation of the net primary production. Ecology 49: 147-149

Macintosh, D. J. (1983\}. Fisheries and aquaculture significance of mangrove swamps, with special reference to the Indo-West Pacific region. In: Muir, J. F., Roberts, R. J. (eds.) Recent advances in aquaculture. Croom Helm, London, p. 5-85

Maltby, E. (1986). Waterlogged wealth. Earthscan Paperbacks, London

Marinucci, A. C. (1982). Trophic importance of Spartina alterniflora production and decomposition to the marshestuarine ecosystem. Biol. Conserv. 22: 35-58

Mason, C. F., Bryant, R. J. (1975). Production, nutrient content and decomposition of Phragmites communis Trin., Typha angustifolia L. J. Ecol. 63: 71-95

Matoh, T., Matsushita, N., Takahashi, E. (1988). Salt tolerance of the reed plant Phragmites communis. Physiologia Pl. 72 8-14

Mook, J.H., Van der Toorn, J. (1982). The influence of environmental factors and management of Phragmites australis II. Effects on yield and its relationships with shoot density. J. appl. Ecol. 19: 501-517

Odum, H. T (1983). Systems ecology. Wiley Interscience, New York

Odum, W. E., Heywood, M. A. (1978). Decomposition of intertidal freshwater marsh plants. In: Good, R. E., Whigham, D. F., Simpson, R. L. (eds.) Freshwater wetlands: ecological processes and management potential. Academic Press, New York, p. 89-97

Odum, W. E., Smith III, T. J., Hoover, J. K., McInvor, C. C. (1984). The ecology of tidal freshwater marshes of the United States east coast: a community profile. U.S. Fish. Wildl. Serv. FWS/OBS-83/17 1-177

Olson, J. S. (1963). Energy storage and the balance of producers and decomposers in ecological systems. Ecology 44: 322-331

Phillips, J. D. (1987). Shoreline processes and establishment of Phragmites australis in a coastal plain estuary. Vegetatio 71: $139-144$

Pierce, S. M. (1983). Estimation of the non-seasonal production of Spartina maritima (Curtis) Fernald in a south African estuary. Estuar. coast. Shelf Sci. 16: 241-254

Polunin, N. V C. (1982). Effects of the freshwater gastropod Planorbis carinatus on reed (Phragmites australis) litter microbial activity in an experimental system. Freshwat. Biol. 12: 547-552

Roberts, M. J., Long, S. P., Tiesen, L. L., Beadle, C. L. (1985). 
Measurement of plant biomass and net primary production. In: Coombs, J., Hall, D. O., Long, S. P., Surlock, J. M. O. (eds.) Techniques in bioproductivity and photosynthesis. Pergamon Press, Oxford, p. 1-19

Robertson, A. I. (1988). Decomposition of mangrove leaf litter in tropical Australia. J. exp. mar. Biol. Ecol. 116: 235-247

Roman. C. T., Daiber, F. C. (1984). Aboveground and belowground primary production dynamics of two Delaware Bay tidal marshes. Bull. Torrey Bot. Club 111: 34-41

Roman, C. T., Niering, W. A., Warren, R. S. (1984). Salt marsh vegetation changes in response to tidal restriction. Envir. Mgmt 8: 141-150

Schleyer, M. H., Roberts, G. A. (1987). Detritus cycling in a shallow coastal lagoon in Natal, South Africa. J. exp. mar. Biol. Ecol. 110: 27-40

Shew, D. M., Linthurst, R. A., Seneca, E. D. (1981). Comparison of production computation methods in a southeastern North Carolina Spartina alterniflora salt marsh. Estuaries 4: 97-109

Steinke, T. D., Ward, C. J. (1987). Degradation of leaf litter in the St. Lucia Estuary as influenced by season and exposure. S. Afr. J. Bot. 53: 323-328

Teal, J. M. (1962). Energy flow in the salt marsh ecosystem of Georgia. Ecology 43: 614-624

Thompson, D. J., Shay, J. M. (1985). The effects of fire on Phragmites australis in the Delta Marsh, Manitoba. Can. J. Bot. 63: 1864-1869

Twilley, R. R., Lugo, A. E., Patterson-Zucca, C. (1986). Litter

This article was submitted to the editor production and turnover in basin mangrove forests in southwest Florida. Ecology 67: 670-683

Ulrich, K. E., Burton, T. M. (1985). The effects of nitrate, phosphate and potassium fertilization on growth and nutrient uptake patterns of Phragmites australis (Cav.) Trin. ex Steudel. Aquat. Bot. $21 \quad 53-62$

Valiela, I. (1984). Marine ecological processes. Springer-Verlag, New York

Van der Toorn, J., Mook, J. H. (1982). The influence of environmental factors and management on stands of Phragmites australis. I. Effects of burning, frost and insect damage on shoot density and shoot size. J. appl. Ecol. 19: $477-499$

Waisel, Y. (1972). Biology of halophytes. Academic Press, London

Whigham, D. F., McCormick, J., Good, R. E., Simpson, R. L. (1978). Biomass and primary production in freshwater tidal wetlands of the middle Atlantic coast. In: Good, R. E., Whigham, D. F., Simpson, R. L. (eds.) Freshwater wetlands: ecological processes and management potential. Academic Press, New York, p. 3-20

Wiegert, R. G., Evans, F. C. (1964). Primary production and the disappearance of dead vegetation on an old field in southern Michigan. Ecology 45: 49-63

Yamasaki, S., Tange, I. (1981). Growth responses of Zizania latifolia, Phragmites australis and Miscanthus sacchariflorus to varying inundation. Aquat. Bot. 10: 229-239

Manuscript first received: October 10, 1989

Revised version accepted: May 25, 1990 